\title{
Salinity Induced Apoptosis in Root Meristematic Cells of Rice
}

\author{
Mojtaba Yazdani and Majid Mahdieh
}

\begin{abstract}
Salt stress is one of the most serious problems in agriculture and can induce apoptosis in plants. Cell death is induced by two modes: apoptosis and necrosis. We used a TUNEL assay and DNA gel electrophoresis on NaCl-treated cells of rice root to morphologically distinguish the mode of cell death in salt-sensitive and salt-tolerant rice cultivars. The results indicated that $500 \mathrm{mmol} / \mathrm{L} \mathrm{NaCl}$ treatments could lead to specific features of apoptosis in root tips in both cultivars, such as DNA ladder, nuclear condense and deformation, and transferase mediated dUTP nick end labeling positive reaction, which were initiated at $4 \mathrm{~h}$ of treatment and progressed thereafter.
\end{abstract}

Index Terms—Apoptosis, salt stress, rice, TUNEL

\section{INTRODUCTION}

Programmed cell death (PCD) or apoptosis occurs during development and in response to different environmental cues [1-6]. Apoptosis exhibits several distinct morphological features, including condensation of cytoplasm, fragmentation of nucleosomal DNA, condensation of nuclear chromatin, membrane blabbing, and appearance of apoptotic bodies [7-9]. Changes in the nucleus provide the most important means of diagnosing apoptosis. In animal cells, the chromatin condenses and collapses into patches, the nucleus becomes fragmented and the cell parts (some of them contain fragmented nucleus) bud outwards to produce membrane-coated apoptotic bodies [10]. Although cytoplasm condensation occurs in animal cells, it is not indicative of apoptosis in the absence of typical nuclear changes [11]. It has been demonstrated that environmental stress, as well as fungal infections, can induce apoptosis [12-15]. Salt stress is one of the most serious problems in agriculture in arid and semi-arid areas. Unfortunately, the cellular mechanisms of salt injury in roots are scarcely known. Among the root cells, meristematic cells are especially interesting, because mitotic activity and cell division are indispensable for root growth and because meristematic cells are considered to be one of the salt-sensitive cells [16]. These cells have been studied under exposure to moderate salinity [17, 18], but not under more severe salt stress. Rice is an important crop worldwide, and is also considered to be a model plant for monocots

Manuscript received January 1, 2012; revised January 30, 2012. This work was supported in part by Islamic Azad University, Ashtian Branch.

Mojtaba Yazdani is with the Department of Biology, Ashtian Branch, Islamic Azad University, Ashtian, Iran (corresponding author, phone: +988627226242; fax: +988627222627; e-mail: yazdani@mail.aiau.ac.ir).

Majid Mahdieh is with the Department of Biology, Faculty of Science, Arak University, Arak, 38156-8-7349, Iran because of its relatively small genome size. Investigation of PCD induced by environmental stresses with the aim of gaining better knowledge about tolerance mechanisms in rice has both fundamental and economic importance. However, little is known about the induction of PCD in rice by salt stress and early events during the induction process. In this study, it was examined if salt stress could induce PCD in rice root tip cells. We also studied the nuclear DNA for biochemical changes.

\section{MATERIALS AND METHODS}

\section{A. Rice Germination and Cell Death Induction}

Seeds of rice (Oryza sativa L.) salt-sensitive (Khazar) and salt tolerant (Zayandehrood) cultivars were sterilized in $0.1 \% \mathrm{HgCl}_{2}$ for $8 \mathrm{~min}$ and soaked in double-distilled $\mathrm{H}_{2} \mathrm{O}$ for 2 d. After germination, seeds were sown on plastic plates, which had many small pores and could float above the nutrient Hoagland solution. When roots were approximately $2 \mathrm{~cm}$ long, seedlings were treated with different concentrations of $\mathrm{NaCl}$ in the nutrient solution for certain times. All of the above procedures were conducted in the dark at $28^{\circ} \mathrm{C}$.

\section{B. DNA Extraction and Agarose Gel Electrophoresis}

DNA extraction was carried out according to Doly and Doly [19]. Briefly, $0.5 \mathrm{~g}$ root tips with or without salt treatment were ground into fine power with liquid nitrogen, transferred into an extraction buffer $(0.1 \mathrm{~mol} / \mathrm{L}$ Tris- $\mathrm{HCl}, 50$ $\mathrm{mmol} / \mathrm{L}$ EDTA, $2 \%$ CTAB, $0.2 \% \beta$-mercaptoethanol), and incubated at $65^{\circ} \mathrm{C}$ for $40 \mathrm{~min}$. Then DNA was extracted with chloroform-isoamyl alcohol (24:1) and precipitated with isopropanol. Pellets were washed with a washing buffer ( $76 \%$ ethanol, $10 \mathrm{mmol} / \mathrm{L}$ ammonium acetate), and dissolved in a TE buffer $(10 \mathrm{mmol} / \mathrm{L}$ Tris- $\mathrm{HCl}, 1 \mathrm{mmol} / \mathrm{L}$ EDTA, $\mathrm{pH}$ 7.4). DNase-free RNase A was used to digest existing RNA. DNA concentration determined by measuring the absorbance at $260-280 \mathrm{~nm}$. Finally, $10 \mathrm{ng}$ of extracted genomic DNA was loaded and fractioned on $2 \%$ agarose gels; gels were stained with ethidium bromide and photographed.

\section{In Situ Terminal Deoxynucleotidyl TUNEL Detection}

The TUNEL reaction (TdT-mediated deoxy-uracil nick end labeling) is used for analyzing DNA fragmentation by labeling the $3^{\prime}-\mathrm{OH}$ ends of the DNA strand breaks. This method is based on the ability of terminal deoxynucleotidyl transferase (TdT) to attach a fluorescein-conjugated deoxy-uracil to the 3 '-OH end of cut DNA [20]. In situ nick end labeling of nuclear DNA fragmentation was carried out for $1 \mathrm{~h}$ in a humidity chamber in the dark at $37^{\circ} \mathrm{C}$ with a 
commercially available TUNEL kit (fluorescein, in situ cell death detection kit) (Takara, Japan) in root sections. After rinsing for $3 \times 5$ min with phosphate buffered saline (PBS) $(\mathrm{pH} 7.4)$, the slides were visualized with an OLMYPUS BX60 fluorescence microscope.

\section{Nuclear Staining and Fluorescent Observation}

Roots were separated from shoots and fixed with FAA for $3 \mathrm{~h}$. After replacement of water with ethanol, fixed roots were embedded in paraffin. Samples were sliced $10 \mu \mathrm{m}$ thick, stained with Hoechst solution and observed with a fluorescent microscope. Stained nuclei showed blue fluorescence with UV excitation.

\section{E. Sodium and Potassium Determination}

For the analysis of sodium and potassium in shoot, $200 \mathrm{mg}$ of dried material was ashed in a muffle furnace at $550^{\circ} \mathrm{C}$ for 8 h. The ashes were digested with $1 \mathrm{ml}$ of $2.5 \mathrm{~N} \mathrm{HCl}$. After appropriate dilutions, the filtrate was assayed for Sodium $\left(\mathrm{Na}^{+}\right)$and potassium $\left(\mathrm{K}^{+}\right)$concentrations using flame photometer.

\section{F. Statistical Analysis}

The data of all experiments were subjected to analysis by One-Way ANOVA $(\mathrm{P}<0.05$, Duncken test) using SPSS 11 program.

\section{RESULtS}

\section{A. DNA Laddering During Salt Stressed Rice Root Tips}

When PCD occurs, activities of nuclease(s) will increase and cleave the whole DNA into fragments regularly, which can be shown on agarose gel after electrophoresis in a DNA ladder with a space of $180 \mathrm{bp}$ nucleasomal units. This is one hallmark of PCD in plants. In the present study, we first used five different concentrations of $\mathrm{NaCl}$ to determine which suitable $\mathrm{NaCl}$ concentration should be selected. We found that treatment with $500 \mathrm{mmol} / \mathrm{L} \mathrm{NaCl}$ could induce the DNA ladder successfully in salt-sensitive and salt-tolerant cultivars, in contrast with other treatment concentrations (Figure 1). Then, we examined the time effects of $500 \mathrm{mmol} / \mathrm{L} \mathrm{NaCl}$ treatment on the process of DNA fragmentation, and found there was apparent progress in DNA cleavage with the time over which salt stress was applied: DNA laddering occurs after $4 \mathrm{~h}$ treatment.

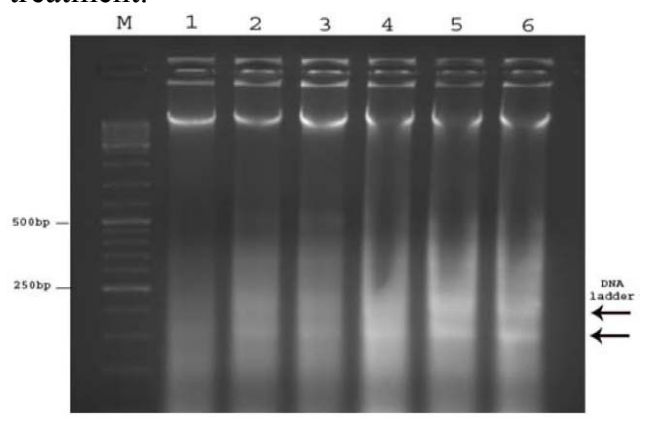

Fig. 1. DNA laddering in rice root tips after salt treatment. DNA laddering after $4 \mathrm{~h}$ treatment with different concentrations of $\mathrm{NaCl}$. Lane $\mathrm{M}$, marker; lane 1, control; lane 2, stressed with $100 \mathrm{mmol} / \mathrm{L} \mathrm{NaCl}$; lane 3, stressed with $200 \mathrm{mmol} / \mathrm{L} \mathrm{NaCl}$; lane 4 , stressed with $300 \mathrm{mmol} / \mathrm{L} \mathrm{NaCl}$; lane 5 , stressed with $400 \mathrm{mmol} / \mathrm{L} \mathrm{NaCl}$; lane 6 , stressed with $5400 \mathrm{mmol} / \mathrm{L} \mathrm{NaCl}$

\section{B. Changes of Chromosome and Nucleus during Salt Stressed Rice Root Tip Cells}

In addition to DNA laddering on agarose gel, PCD also can be manifested by nuclear changes and DNA fragmentation in situ. In this experiment, we used a transferase mediated dUTP nick end labeling (TUNEL) assay kit. The results indicated that the nucleus of root tip cells appear brown in color (TUNEL-positive) after $4 \mathrm{~h}$ treatment in both cultivars (Fig. 2b,c), while the nucleus of control root tip cells remain green in color (TUNEL-negative) (Fig. 2a). Taken together, our results showed that high salt stress could induce PCD in rice root tip cells, and the nuclear events of the PCD occurred from $4 \mathrm{~h}$ of treatment.

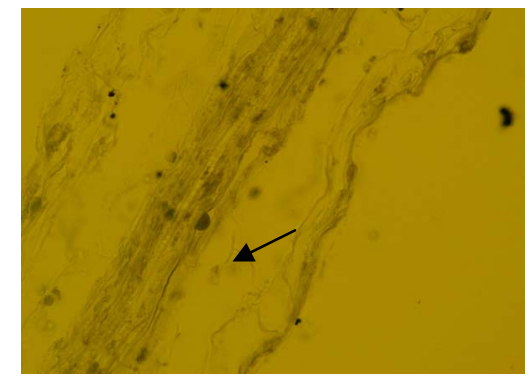

(a)

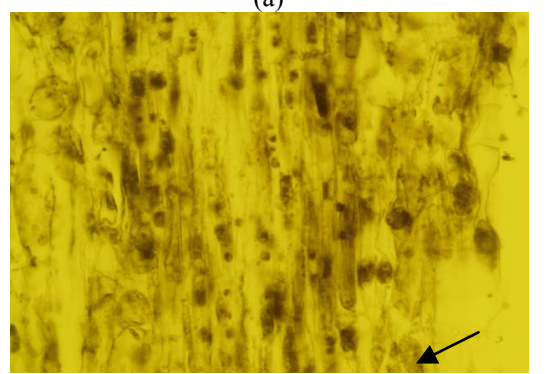

(b)

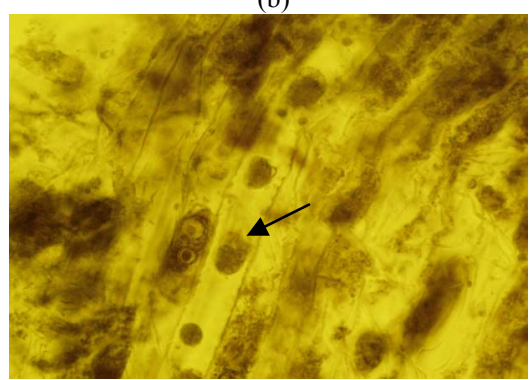

(c)

Fig. 2. In situ TUNEL labeling for rice root tip cells after $500 \mathrm{mmol} / \mathrm{L}$ $\mathrm{NaCl}$ treatment. (A) Control (40x), (B) Stressed for $4 \mathrm{~h}$ in Khazar cultivar (40x). (C) Stressed for $4 \mathrm{~h}$ in Zayandehrood cultivar (40x).

\section{Nuclear Staining and Fluorescent Observation}

Hoechst-stained nuclei showed blue fluorescence with UV excitation. The results indicated that the nucleus of root tip cells became smaller and condensed after $4 \mathrm{~h}$ treatment in both cultivars (Figure 3 ).

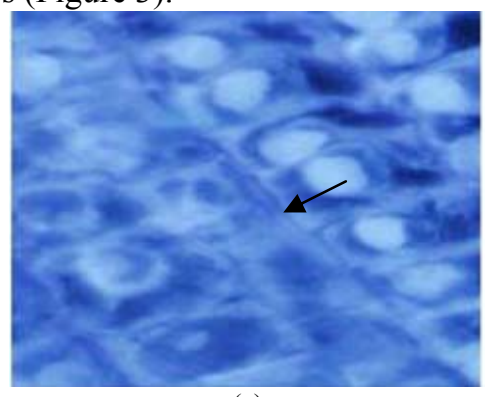

(a) 


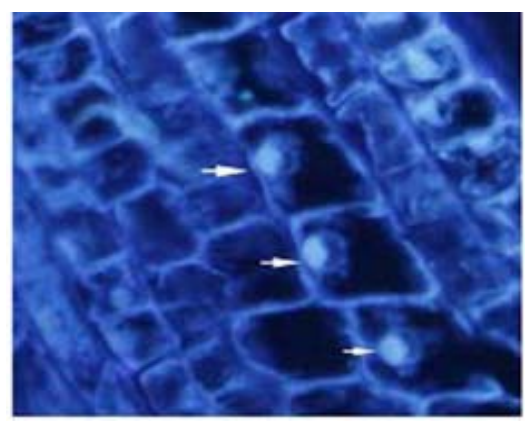

(b)

Fig. 3. Fluorescent micrographs of a, meristem of control root; b, meristem of root treated with $500 \mathrm{mM} \mathrm{NaCl}$ for $4 \mathrm{~h}$. Nucleuses were stained with Hoechst dye.

\section{Effects of Salt Stress on Ion Uptake}

$\mathrm{Na}^{+}$amount increased markedly in response to increasing stress level (Figure 4a) in both cultivars. However $\mathrm{K}^{+}$amount increased markedly in response to salt stress in Zayandehrood, but there was no significant difference in the $\mathrm{K}^{+}$content in Khazar (Figure 4b).

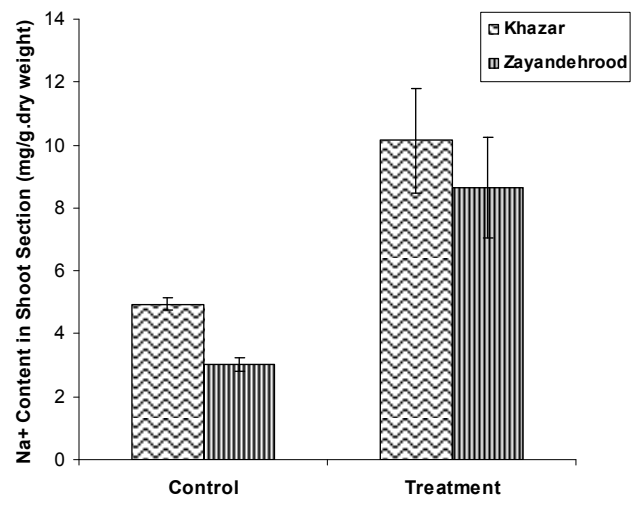

(a)

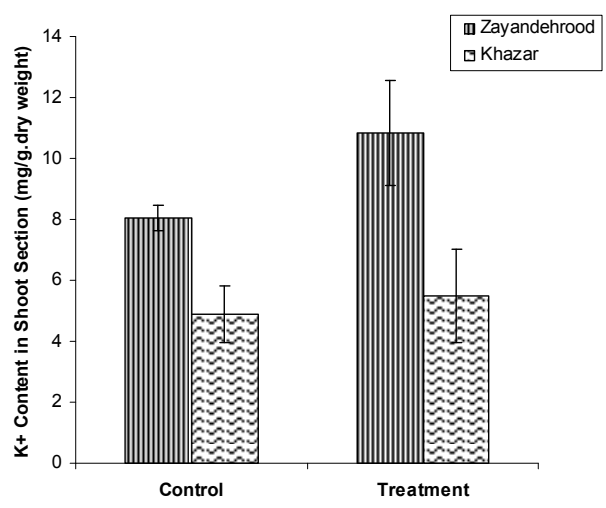

(b)

Fig. 4. $\mathrm{Na}^{+}$and $\mathrm{K}^{+}$amount of shoot section in rice plant after $100 \mathrm{mmol} / \mathrm{L}$ $\mathrm{NaCl}$ treatment for $4 \mathrm{~h}$. (a) $\mathrm{Na}^{+}$content and (b) $\mathrm{K}^{+}$content.

\section{DISCUSSION}

The DNA ladder and TUNEL positive reaction are considered as two hallmarks of PCD in both mammals and plants. In this research, our results indicate that $500 \mathrm{mmol} / \mathrm{L}$ $\mathrm{NaCl}$ can induce both of the above PCD features in rice root tip cells after $4 \mathrm{~h}$ treatment in both salt-sensitive and salt-tolerant cultivars. Furthermore, this research also indicates that salt stress can induce nuclear condensation in rice roots. It is postulated that salt-induced PCD of rice primary roots is a component of an adaptive response. Cellular $\mathrm{Na}^{+}$toxicity is the predominant ion toxicity caused by salinity stress, resulting in the inhibition of a variety of processes such as $\mathrm{K}^{+}$absorption [21]. A conserved primary salt tolerance mechanism mediated by HKT transporters, which absorb $\mathrm{Na}^{+}$ions into the xylem parenchyma cell from the xylem vessel and triggers $\mathrm{K}^{+}$secretion into the xylem vessel [22]. In summary, mechanisms of salt tolerance are of two main types: those minimizing the entry of salt into the plant (or at least their accumulation in photosynthetic tissues) and those minimizing the concentration of salt in the cytoplasm [23]. Hypoxia-induced aerenchyma formation is a well documented adaptation required for plant roots to maintain oxygen status. Aerenchyma differentiation requires elimination of root cortical cells that is mediated through PCD [24-26]. Similarly to the results presented here for rice, barley seedlings develop new roots after salt induced cell death causes senescence of the primary root [27]. Salt-induced PCD in plant roots is probably an adaptation required for salt tolerance-the elimination of a primary root that makes the plant vulnerable to a saline environment and replacement with roots that can facilitate nutrient and water acquisition yet restrict salt influx through the transpirational stream.

\section{ACKNOWLEDGEMENTS}

This paper is extracted from the research project at title: "The survey of intraction between salt tolerance and apoptosis in the roots of tolerant and sensitive iranian rice cultivars" in Islamic Azad University, Ashtian Branch. Authors would like to thank administer and head of technology section in of the Islamic Azad University, Ashtian Branch.

\section{REFERENCES}

[1] J. T. Greenberg, Programmed cell death: a way of life for plants, Proc. Natl. Acad. Sci. U.S.A. 1996, (93): 12094-12097.

[2] R. I. Pennell and C. Lamb, Programmed cell death in plants, Plant Cell, (9): 1157-1168, 1997.

[3] M. C. Drew, C. J. He, and P. W. Morgan, Programmed cell death and aeranchyma formation in roots, Trends Plant Sci. (5): 123-127, 2000.

[4] E. Liljeroth and T. Bryngelsson, DNA fragmentation in cereal roots indicative of programmed root cortical cell death, Plant Physiol. (111): 365-372, 2001.

[5] L. Hovel and D. J. Durzan, Apoptosis in plants, Bot. Acta, (109): 268-277, 1996.

[6] T. Yamada, Y. Takatsu, T. Manabe, M. Kasumi, and W. Marubashi, Suppressive effect of trehalose on apoptotic cell death leading to petal senescence in ethylene-insensitive flowers of gladious, Plant Sci. (164): 213-221, 2003.

[7] J. F. Kerr, A. H. Wyllie, and A. R. Currie, Apoptosis: a basic biological phenomenon wide-ranging implications in tissue kinetics, Br. J. Cancer. (26): 239-257, 1972.

[8] J. F. Kerr, J. Searle, B.V. Harmon, and C. J. Bishop, Apoptosis: perspective on mammalian cell death, Oxford University Press, New York, pp. 68-82, 1987.

[9] A. H. Wyllie, J. F. Kerr, and A. R. Currie, Cell death: the significance of apoptosis, Int. Rev. Cytol. (85): 251-306, 1980.

[10] J. J. Cohn, Apoptosis, Immunol. Today. (14): 126-130, 1993.

[11] J. F. Kerr, C. M. Winterford, and B.V. Harmon, Cell Biol: A Laboratory Handbook, Academic Press, London, pp. 121-129, 1994. 
[12] L. Fesus, P. J. Davies, and M. Piacentini, Apoptosis: molecular mechanisms in programmed cell death, Eur. J. Cell Biol. (56): 170-177, 1991.

[13] M. C. Heath and D. E. Ryerson, Cleavage of oligonucleosomal fragments during cell death induced by fungal infection or by abiotic treatment, Plant Cell, (8): 393-402, 1996.

[14] A. Levine, R. I. Pennel, M. E. Alvarez, R. Palmar, and C. Lamb, Calcium-mediated apoptosis in a plant hypersensitive disease resistance response, Curr. Biol. (6): 427-437, 1996.

[15] R. Mittler and E. Lam, Sacrifice in the face of foes: pathogen-induced programmed cell death in plants, Trends Microbiol. 1996, (4): 10-15.

[16] C. X. Huang and R. F. M. Van Steveninck, Effect of moderate salinity on patterns of potassium, sodium and chloride accumulation in cells near the root tip of barley: role of differentiating metaxylem vessels. Physiol. Plant. (73): 525-533, 1988 .

[17] E. Werker and H. R. Lerner, Weimberg, R. and Poljakoff-Mayber, A. Structural changes occurring in nuclei of barley root cells in response to a combined effect of salinity and ageing. Amer. J. Bot. (70): 222-225, 1983.

[18] C. X. Huang and R. F. M. Van Steveninck, Salinity induced structural changes in meristematic cells of barley roots. New Phytol. (115): 17-22, 1990.
[19] J. J. Doyle and J. L. Doyle, Isolation of plant DNA from fresh tissue. Focus, (12): 13-15, 1990.

[20] Y. Gaverieli, Y. Sherman, and S. A. Ben-Sasson, "Identification of programmed cell death in situ via specific labeling of nuclear DNA fragmentation," J. Cell Biol. 119, 493-501, 1992.

[21] D. W. Rains and E. Epstein, Transport of sodium in plant tissue. Science, 148: 1611, 1965.

[22] F. Hauser and T. Horie: A conserved primary salt tolerance mechanism mediated by HKT transporters: a mechanism for sodium exclusion and maintenance of high $\mathrm{K}^{+} / \mathrm{Na}^{+}$ratio in leaves during salinity stress. Plant, Cell and Environment, 33: 552-565, 2010.

[23] R. Munns, Comparative physiology of salt and water stress, Plant Cell Environment, 25: 239-250, 2002.

[24] M. C. Drew, C.-J. He, and P. W. Morgan, Programmed cell death and aerenchyma formation in roots. Trends Plant Sci. 2000, (5): 123-127.

[25] H. Mergemann and M. Sauter, Ethylene induces epidermal cell death at the site of adventitious root emergence in rice. Plant Physiol. (124): 609-614, 2000.

[26] C. C. Subbaiah, K. P. Kollipara, and M. M. Sachs, $\mathrm{A} \mathrm{Ca}^{2+}$-dependent cystein protease is associated with anoxia-induced root tip death in maize, J. Exp. Bot. (51): 721-730, 2000.

[27] M. Katsuhara and M. Shibasaka, Cell death and growth recovery of barley after transient salt stress, J. Plant Res. (113): 239-243, 2000. 